\title{
EMPLOYER HEALTH BENEFIT COSTS AND DEMAND FOR PART TIME LABOR
}

\author{
by
}

\author{
Jennifer Feenstra Schultz* \\ University of Minnesota
}

and

David Doorn

University of Minnesota

CES 09-08 April, 2009

The research program of the Center for Economic Studies (CES) produces a wide range of economic analyses to improve the statistical programs of the U.S. Census Bureau. Many of these analyses take the form of CES research papers. The papers have not undergone the review accorded Census Bureau publications and no endorsement should be inferred. Any opinions and conclusions expressed herein are those of the author(s) and do not necessarily represent the views of the U.S. Census Bureau. All results have been reviewed to ensure that no confidential information is disclosed. Republication in whole or part must be cleared with the authors.

To obtain information about the series, see www.ces.census.gov or contact Cheryl Grim, Editor, Discussion Papers, U.S. Census Bureau, Center for Economic Studies 2K130B, 4600 Silver Hill Road, Washington, DC 20233, Cheryl.Ann.Grim@census.gov. 


\begin{abstract}
The link between rising employer costs for health insurance benefits and demand for part-time workers is investigated using non-public data from the Medical Expenditure Panel SurveyInsurance Component (MEPS-IC). The MEPS-IC is a nationally representative, annual establishment survey from the Agency for Healthcare Research and Quality (AHRQ). Pooling the establishment level data from the MEPS-IC from 1996-2004 and matching with the Longitudinal Business Database and supplemental economic data from the Bureau of Labor Statistics, a reduced form model of the percent of total FTE employees working part-time is estimated. This is modeled as a function of the employer health insurance contribution, establishment characteristics, and state-level economic indicators. To account for potential endogeneity, health insurance expenditures are estimated using instrumental variables (IVs). The unit of analysis is establishments that offer health insurance to full-time employees but not part time employees. Conditional on establishments offering health insurance to full-time employees, a 1 percent increase in employer health insurance contributions results in a 3.7 percent increase in part-time employees working at establishments in the U.S.
\end{abstract}

Keywords: employer health insurance costs; labor demand; part-time employment

* Corresponding author: Department of Economics, Labovitz School of Business and Economics, University of Minnesota, 412 Library Drive 165 SBE, Duluth, MN; Phone: 218-7266695; Fax: 218-726-6509; E-mail: jschultz@d.umn.edu. The research in this paper was conducted while the authors were Special Sworn Status researchers of the U.S. Census Bureau at the Chicago Census Research Data Center. Research results and conclusions expressed are those of the authors and do not necessarily reflect the views of the Census Bureau. This paper has been screened to ensure that no confidential data are revealed. Support for this research at the Chicago RDC from NSF (ITR-0427889) is also gratefully acknowledged. 


\section{Introduction}

The latest report from the Census Bureau indicates the United States has continued to experience annual increases in the number of people without health insurance coverage in recent years. Despite a brief period of declines in 1999 and 2000, the overall percentage of the population with no health insurance rose from 12.9 percent in 1987 to 15.8 percent in 2006 (DeNavas-Walt et al, 2007 or U.S. Census Bureau, 2007). Of those under age 65 , the proportion of the population covered by employment based insurance has fallen from 68.3 percent in 2000 to 62.9 percent in 2006, a decline of 5.4 percentage points, representing 3.9 million fewer men, women, and children with access to insurance provided through either their own or a family member's employer. Focusing on employee coverage in particular, additional data indicates that the proportion of U.S. workers with employer-sponsored insurance declined from 81.2 percent in 2001 to 77.4 percent in 2005 , with nearly half of this decline due to a decrease in employer sponsorship and the rest evenly split between lost eligibility for workers and an increase in non-participation of eligible employees (Clemens-Cope, Garrett, and Hoffman, 2006).

With health insurance costs comprising a large and growing share of total compensation paid to U.S. employees it is perhaps not surprising that coverage rates have been declining as firms look to cut labor costs. Non-wage benefits were only 3 percent of total compensation for the average U.S. worker in 1929 and 17 percent in 1955, but in 2007 they accounted for 30.2 percent (BLS; Compensation and Working Conditions Report, BLS 2001). Moreover, employer expenditures on health insurance and other non-wage benefits have increased 50 percent faster than wages over the last ten years (CMS, National Health Statistics). This could well affect labor market outcomes. IRS 
non-discrimination rules bar employers from offering such benefits to just select employees. If they are offered to any, then they must be available to all full-time workers at the firm, otherwise there are potential tax consequences that reduce the desirability of providing benefits at all. As a result, rather than dropping coverage of all employees as a means of reducing costs, which could make the firm less attractive in the labor market, rising health insurance costs may cause pervasive structural changes in how firms assemble their workforce. This could include movement away from regular full-time employees to greater use of part-time and/or temporary workers, or even outsourcing of jobs that previously had been kept in-house. If this is happening, then the rise in benefit costs is distorting labor market outcomes from what may otherwise be the optimal mix of employment between full-time and part-time workers.

In this study we investigate the link between rising employer costs for health insurance benefits and demand for part-time workers using non-public data from the expansive Medical Expenditure Panel Survey-Insurance Component (MEPS-IC). The results of this study provide additional evidence of the impact rising health insurance costs may have on the labor market, offering one possible explanation for the trends in coverage rates for working Americans. This also should inform the policy debate on alternative sources for medical insurance coverage, whether it is best funded through the private sector or whether it may require at least some government intervention.

There is extensive literature in the field of labor economics that provides a theoretical framework and empirical models of labor demand by firms. While several studies report the effects of fringe benefit costs on wages and the demand for labor, there are only a few 
that explicitly analyze the effects of health insurance costs. Furthermore, because some costs are fixed while others are quasi-fixed or variable, it is often difficult to interpret the results from studies that lump all benefit costs together. The general equilibrium model of the labor market suggests that when labor costs rise from an increase in health benefit costs (a quasi-fixed labor cost), the demand for labor will fall, leading to lower wages and employment. However, as suggested by Summers (1989) and Feldman (1993), if employees value health insurance more than the increase in health benefit costs and if they are poorer as a result of higher health costs and a fall in wages, they may increase their supply of labor, contributing to a further decrease in wages but increasing the level of employment. If employees do not value the increase in health benefit costs, then the costs would not be fully shifted to wages, and employment would fall. The implications of this labor market model are that rising health benefit costs should lead to lower wages but the effect on employment is ambiguous. Since there are limits on employers' ability to lower wages by the amount of the increase in health benefit costs as a result of minimum wage laws or union contracts, employers may increase the hours worked by full-time employees rather than hiring new workers, or replace full-time employees with part-time employees who are not eligible for health benefits. Therefore the effect of rising health benefits costs may increase or decrease the hours of work and employment of workers. Since the theoretical model results are ambiguous with respect to hours of work and employment, the question of the effects of rising health benefit costs on these dimensions must be addressed empirically. In addition to the effects on wages, hours and employment, employers may drop health insurance coverage entirely or may decrease the 
level of health benefits, such as replacing fee-for-service plans with HMO type products or health savings accounts that have high deductibles and more cost sharing.

We specifically report findings from the literature on health benefits and wages, hours and employment. ${ }^{1}$ Gruber (1994) uses an exogenous change in health benefit coverage to study the effect on wages. He studied the effect of an employer mandate of health insurance coverage for childbirth and found a decline in wages for married 20-40 year old women, the group affected by the mandate. Thus, the increase of health benefit costs resulted in lower wages to those who could potentially benefit from the additional coverage. Other studies found similar results of shifting the costs of health benefit coverage to wages (Sheiner 1995, Olson 1994). Though, Buchmueller and Lettau (1997) did not find a negative relationship between wages and health insurance costs when analyzing data on job-specific information on wages and insurance costs over time.

Ehrenberg and Schumann (1984) present a comprehensive review of literature on fringe benefit costs and use of overtime labor at the firm and industry level. They find that a 10 percent increase in fringe benefit costs leads to a 5-17 percent increase in overtime hours per worker. Using data from the CPS from 1980-1993 and the 1984-1992 panels of the Survey of Income and Program Participation (SIPP), Cutler and Madrian (1998) find that hours of work increased for individuals with health insurance coverage by .06 to .10 hours per week each year compared to individuals without coverage.

A related line of research evaluates the effect of fixed labor costs on the employment of full- versus part-time labor. In an early study by Owen (1979) the ratio of part- to fulltime employees is lower in industry-occupation cohorts that have higher indirect labor costs. In a later study Montgomery and Costgrove (1993) find that higher fringe benefit

\footnotetext{
${ }^{1}$ The literature on wages and fringe benefits is summarized nicely by Gruber (2000).
} 
payments are related to declines in hours worked by part-time employees. However, they found no evidence that child care centers paying high benefits to full-time employees demand more part-time workers. Montgomery (1988) finds conflicting results for the relationship between higher fixed costs and demand for full-time employees.

Buchmueller (1999) uses cross-sectional establishment data from a survey of California employers conducted in 1993 to investigate the relationship between fringe benefit costs and demand for part-time employees. He finds that increasing benefits paid to full-time workers by one dollar will increase the percentage of workers employed parttime by 8 percentage points, with a larger effect on the demand for lower skill part-time employees. Using Current Population Survey data, supplemented with health insurance premium data from the Kaiser Family Foundation/HRET survey and malpractice payment data from the National Practitioner Data Bank, Baicker and Chandra (2005) find that a 20 percent increase in health insurance premiums reduces the probability of being employed by 3 percentage points ( 4 million workers), a one hour reduction in the average number of hours worked per week, a movement of approximately 4 million workers from full-time to part-time status, and a reduction of annual income by $\$ 2,000$ for employees with health insurance coverage. In general, these findings provide some evidence that employers are increasing the percent of their workforce that do not qualify for benefits in response to rising fixed employment costs, but there is no strong consensus on the relationship between higher fixed labor costs and the demand for full- and part-time employment.

By analyzing more recent establishment data we hope to fill gaps in existing studies in this area. Further, this study complements existing studies that use individual- 
level data to study the effects of health insurance benefit costs on wages and hours worked.

\section{Data Sources}

The primary data source is the Medical Expenditure Panel Survey-Insurance Component (MEPS-IC) List Sample 1996-2004. MEPS-IC is a nationally representative, annual establishment survey of characteristics of employer-sponsored health insurance funded by the Agency for Healthcare Research and Quality (AHRQ) and collected by the U.S. Census Bureau. MEPS-IC is a survey of both private and public sector establishments with data currently available from 1996 through 2004. To supplement the MEPS-IC survey, public-use data collected by the Bureau of Labor Statistics is used to identify economic indicators such as state unemployment rates. Pooling the private establishment level data from the MEPS-IC over several years and matching with the Longitudinal Business Database and supplemental economic data from the Bureau of Labor Statistics, we estimate a reduced form model of the percent of total FTE employees working part-time at each establishment. This is modeled as a function of the employer contribution to health insurance benefits, establishment characteristics (e.g. type of industry, non-profit status, whether women comprise more than 50 percent of employee workforce, percentage of employees over age 50, whether low-wage workers comprise more than 50 percent of employee workforce, number of years in operation, union presence, firm size), and state-level economic indicators ( percent unemployed, state indicator variables). To account for potential endogeneity, benefit expenditures are estimated as a function of establishment characteristics (e.g. corporation status). We 
account for the timing of the different observations by including year indicator variables in the econometric specification. In a very general way, this captures the impact of the overall rise in healthcare costs over the years data were collected, as well as controls for other aggregate changes in the economy over time. Summary statistics for the variables appear in Table 1.

\section{Methodology}

The private establishment level data from the MEPS-IC list sample is pooled over the years currently available, 1996 through 2004. Because the MEPS-IC is a survey with a rotating sample of establishments each year, it is unlikely that any single establishment will show up in the survey in more than a single survey period, so the data can not be treated explicitly as a time series at the individual establishment level. The survey design and clustering of establishments over time are accounted for in the empirical specification (using survey regression commands in STATA with survey weights and correcting standard errors for clustering within sample strata). The unit of analysis is establishments that offer health insurance to full-time employees but not part-time employees $(\mathrm{N}=37,635)$.

A reduced form model of the percent of total FTE employees working part-time at each establishment is estimated as a function of the cost of health insurance benefits, establishment characteristics, and other characteristics (state dummy variable, countylevel unemployment rates, year indicator variables). To account for potential endogeneity, benefit expenditures are estimated as a function of establishment characteristics. The primary independent variable of interest is the cost of health 
insurance benefits. We calculate the average amount of the health insurance premiums paid by the employer for each employee (weighted to reflect enrollment proportions in single and family coverage plans). The employer contribution is converted to 2004 constant dollars by using the Employment Cost Index for health insurance provided by the Bureau of Labor Statistics National Compensation Survey.

Dummy variables were created to account for missing observations on age of workforce, gender composition, percentage of workforce paid low wages, years of operation, and union status. Only two of these variables (gender composition and years in operation) are statistically significant. Dropping observations with missing values results in similar regression results.

The dependent variable is percent of FTE employees working part-time at each establishment (we assume that two part-time workers supply the same number of hours as one full-time worker). The goal, of course, is to see how this changes in relation to different levels of employer contributions for health insurance coverage. In doing this, we control for other factors which are likely to affect a firm's hiring of part-time employees. The specification is

$\mathrm{PT}_{\mathrm{i}}=\alpha+\beta_{1} * \mathrm{HC}_{\mathrm{i}}+\beta_{\Phi}{ }^{\prime *} \Phi_{\mathrm{i}}+\beta_{\mathrm{YR}} * \mathrm{YR}+\varepsilon_{\mathrm{i}}$

where

$\mathrm{PT}_{\mathrm{i}}=$ percent of FTE employees working part-time at establishment $\mathrm{i}$

$\mathrm{HC}_{\mathrm{i}}=$ employer contribution to health insurance coverage at establishment $\mathrm{i}$

$\Phi_{\mathrm{i}}=\mathrm{a}$ vector of control variables accounting for different establishment characteristics

$\mathrm{YR}=$ vector of indicator variables for each year in study

$\varepsilon_{\mathrm{i}}=$ random error term 
$\Phi_{\mathrm{i}}=\left[\mathrm{IND}_{\mathrm{i}}, \mathrm{NP}_{\mathrm{i}}, \mathrm{U}_{\mathrm{i}}, \mathrm{G}_{\mathrm{i}}, \mathrm{L}_{\mathrm{i}}, \mathrm{OP}_{\mathrm{i}}, \mathrm{Age}_{\mathrm{i}}, \mathrm{ST}_{\mathrm{i}}, \mathrm{UR}_{\mathrm{i}}, \mathrm{FTE}_{\mathrm{i}}\right]$

with

$I N D_{i}=$ vector of dummy variables, one for each industry

$\mathrm{NP}_{\mathrm{i}}=1$ if establishment is a non-profit

$\mathrm{U}_{\mathrm{i}}=1$ if union presence, 0 otherwise

$\mathrm{G}_{\mathrm{i}}=1$ if $>50$ percent of employees are women, 0 otherwise

$\mathrm{L}_{\mathrm{i}}=1$ if $>50$ percent of employees are low-wage $(<\$ 9.50 /$ hour $)$

$\mathrm{OP}_{\mathrm{i}}=$ years in operation (categorical dummy variables)

$\mathrm{Age}_{\mathrm{i}}=$ percent of employees older than age 50

$\mathrm{ST}_{\mathrm{i}}=$ vector of dummy variables for each state

$\mathrm{UR}_{\mathrm{i}}=$ unemployment rate in state where establishment $i$ operates in year YR

$\mathrm{FTE}_{\mathrm{i}}=$ size of establishment as measured by total FTEs

The above equation is estimated by OLS initially to test for specification errors and endogeneity of the regressors. In the previously cited literature, health benefit costs are generally considered to be co-determined to some extent with employment, resulting in endogeneity of $H C,\left(\operatorname{corr}\left(H C_{i}, \varepsilon_{i}\right) \neq 0\right)$. We find that the employer contribution is endogenous making OLS an inconsistent estimator, so we follow previous studies and instrument for HC. Thus we estimate a two-stage least squares (2SLS) model where the first step involves regressing $\mathrm{HC}$ on the instrument and then constructing predicted values of $\mathrm{HC}$ as that portion of $\mathrm{HC}$ not dependent on factors affecting $P T_{i}$, and so orthogonal to $\varepsilon_{i}$. The predicted $\mathrm{HC}_{\mathrm{i}}$ would then be replaced by $H C_{i}$ in the above model. 
We follow Buchmueller (1999) and use a corporate status indicator as an instrument. We use the corporate status dummy because benefit expenses are tax deductible for corporations, but not for sole proprietors or partnerships. Thus this variable should predict the level of employer contributions but not necessarily the demand for part-time workers.

\section{Results}

Results from the 2SLS procedure are presented in Table 2. The standard errors have been adjusted for the use of a fitted regressor. Results from the OLS model and from the first-stage health insurance employer compensation regression are reported in Tables 3 and 4.

The results support the hypothesis that establishments that contribute more to health insurance benefits employ a higher fraction of part-time workers. Specifically results from the 2 SLS model (Table 2) suggest that a 1 percent increase in employer contributions leads to a 3.7 percent increase in the demand for part-time employees at an establishment (which does not offer health insurance coverage to part-time employees). Increasing health insurance benefit compensation to full-time workers by $\$ 100$ annually will increase the percentage of FTE workers employed part-time by 2 percentage points.

OLS results appear in Table 3. The effect of employer health insurance benefit expenditures on the demand for part-time workers is very small in the OLS model with an elasticity of only 0.06 . The small effect is consistent with the hypothesis that there are 
unobserved factors that positively influence the demand for part-time workers but are negatively correlated with an establishment's expenditures on health insurance benefits.

Results from the first stage model of health insurance employer compensation appear in Table 4. The corporation status instrument is a significant predictor of the employer contributions to health insurance. Employer contributions are $\$ 622$ higher in establishments with a union presence. Employer contributions at non-profit establishments are $\$ 970$ higher than in for-profit establishments. Establishments where low-wage workers comprise more than 50 percent of the work force, employer contributions to health insurance benefits are $\$ 463$ less compared to establishments where low wage workers comprise less than 50 percent of the work force. In 2004 employer contributions to health insurance benefits were less than what they had been in 1999 to 2003, after adjusting for inflation using the Employment Cost Index.

We investigated the effect of employer health insurance contributions on the percent of low-wage workers at establishments as well. We were not able to determine the percent of low-wage part-time workers, however. The same specification was used as that in Table 2. The results suggest that a 1 percent increase in employer health insurance contributions is related to a 1.44 percent increase in the demand for low-wage workers. Alternatively, when using the percent of high wage workers as the dependent variable, a 1 percent increase in employer health insurance contributions implies a 5.75 percent decrease in the demand for high-wage workers.

To test the robustness of our results, we estimated models using the percent of employer contribution to health insurance costs and got similar results. We also specified 
the percent of part-time workers at an establishment as a dependent variable. The results are similar to those reported using the percentage of FTE workers who are part-time.

\section{Conclusion}

We estimate the effect of employer contributions to health insurance benefits on the demand for part-time workers at establishments that offer health insurance benefits to full-time workers but not part-time workers. We find that employers offering higher health benefit contributions use a higher percentage of part-time workers. In addition, it appears that employers simultaneously determine the health insurance benefit expenditures and their demand for part-time workers. Thus, treating health insurance benefit expenditures as an exogenous determinant of demand for labor would result in downwardly biased effects.

Our results are consistent with recent evidence that suggests employer health spending has declined due to a decrease in the number of workers covered and the recent increase in contingent employment as a means to reduce benefit expenditures.

Our results are limited to establishments that offered health insurance to full-time employees but not part-time employees. Since our results are conditional on establishments offering health insurance, we plan to evaluate the probability of firms offering health insurance. 


\section{References}

Baicker, Katherine, Chandra, Amitabh. (2005) "The labor market effects of rising health insurance premiums.” NBER Working Paper \#11160. Cambridge, MA.

Buchmueller, Thomas. (1999) "Fringe benefits and the demand for part-time workers." Applied Economics, Vol. 31: 551-563.

Buchmueller, Thomas, DiNardo, John, Valletta, Robert. (2002) "Union effects on health insurance provision and coverage in the United States." Industrial and Labor Relations Review, Vol. 55: 610-627.

Buchmueller, Thomas, Lettau, Michael. (1997) "Estimating the wage-health insurance tradeoff: more data problems?" Mimeo (UC-Irvine).

Chernew, Michael, Frick, Kevin, McLaughlin, Catherine. (1997) "The demand for health insurance coverage by low-income workers: can reduced premiums achieve full coverage?" Health Services Research, Vol. 32(4): 453-70.

Clark, Robert, Shumaker Ghent, Linda, Headen, Alvin. (1994) "Retiree health insurance and pension coverage: variations by firm characteristics." Journal of Gerontology, Vol. 49(2): S53-S61.

Clemens-Cope, Lisa, Garrett, Bowen, Hoffman, Cahterine. (2006). Changes in Employees' Health Insurance Coverage, 2001-2005. Kaiser Commission on Medicaid \& the Uninsured, Issue Paper October.

Cooper, Phillip, Schone, Barbara. (1997) "More offers, fewer takers for employmentbased health insurance." Health Affairs, Vol. 16(6):142-49.

Cutler, David, Madrian, Brigitte. (1998) "Labor market responses to rising health insurance costs: evidence on hours worked." RAND Journal of Economics, Vol. 29(3): 509-530.

Ehrenberg, R., Shumann, P. (1984) Longer Hours or More Jobs? ILR Press, Ithaca.

Farber, Henry, Levy, Helen. (2000) "Recent trends in employer-sponsored health insurance coverage: are bad jobs getting worse?" Journal of Health Economics, Vol. 19(1):93-119.

Feldman, Roger. (1993) "Who pays for mandated health insurance benefits?" Journal of Health Economics, Vol. 11: 341-348.

Freeman, Richard, Medoff, James. (1984) What do unions do? New York: Basic Books. 
Gruber, Jonathan. (1994) "The incidence of mandated maternity benefits." American Economic Review, 84: 622-641.

Gruber, Jonathan. (2000) "Health insurance and the labor market." In Handbook of Health Economics, Vol. 1 edited by A.J. Culyer and J.P. Newhouse.

Gruber, Jonathan, Madrian, Brigitte. (1995) "Health-insurance availability and the retirement decision." American Economic Review, Vol. 85(4): 938-948.

Lettau, Michael, Buchmueller, Thomas. (1999) "Comparing benefit costs for full- and part-time workers.” Monthly Labor Review, Vol. 122 (3): 30-35.

McCormack, Lauren, Gabel, Jon, Berkman, Nancy, Whitmore, Heidi, Hutchinson, Kay, Anderson, Wayne, Pickreign, Jeremy, West, Nathan. (2002) "Retiree health insurance: recent trends and tomorrow's prospects." Health Care Financing Review, Vol. 23(3): 17-34.

Montgomery, Mark. (1988) "On the determinants of employer demand for part-time workers." Review of Economic and Statistics, Vol. 70(1): 394-406.

Montgomery, Mark, Cosgrove, James. (1993) "The effect of employee benefits on the demand for part-time workers." Industrial and Labor Relations Review, Vol.47(1): 87-98.

Olson, C. (1994) "Parttime work, health insurance coverage and the wages of married women." Mimeo (University of Wisconsin-Madison).

Owen, J.D. (1979) Working Hours. Lexington, Mass. Lexington Books.

Papke, Leslie, Wooldridge, Jeffrey. (1996) "Econometric methods for fractional response variables with an application to 401(k) Plan Participation Rates. Journal of Applied Econometrics, 11(6): 619-632.

Rice, Thomas, et al. (1997) "Trends in job-based health insurance." Report submitted to the Kaiser Family Foundation, October.

Rogowski, Jeannette, Karoly, Lynn. (2000) "Health insurance and retirement behavior: evidence from the health and retirement survey." Journal of Health Economics, Vol. 19: 529-539.

Sheiner, L. (1995) “Health costs, aging, and wages.” Mimeo (Federal Reserve Board).

Shore-Sheppard, Lara, Buchmueller, Thomas, Jensen, Gail. (2000) "Medicaid and crowding out of private insurance: a re-examination using firm level data." Journal of Health Economics, Vol. 19(1):61-91. 
Woodbury, S. (1983) "Substitute between wage and non-wage benefits." American Economic Review, Vol. 73: 166-187.

Woodbury, Stephen and Bettinger, Douglas. (1991) "The decline of fringe benefit coverage in the 1980's." In Randall W. Eberts and Erica L. Groshen, eds., Structural Changes in U.S. Labor Markets: Causes and Consequences. New York: M.E. Sharpe, pp. 105-38.

DeNavas-Walt, Carmen, Bernadette D. Proctor, and Jessica Smith, U.S. Census Bureau, Current Population Reports, P60-233, Income, Poverty, and Health Insurance Coverage in the United States: 2006, U.S. Government Printing Office, Washington, DC, 2007.

U.S. Census Bureau. 2007. Income, Poverty, and Health Insurance Coverage in the United States: 2006. Report P60-233. August 2007.

Vaness, David J. and Wolfe, Barbara L. "Government Mandates and EmployerSponsered Health Insurance: Who is Still Not Covered?", International Journal of Health Care Finance and Economics, Vol. 2 (2), June 2002: 99-135. 
Table 1: Descriptive Statistics

\begin{tabular}{|c|c|c|c|c|}
\hline \multirow{2}{*}{ Variables } & \multicolumn{2}{|c|}{ Unweighted } & \\
\hline & Mean & $\begin{array}{l}\text { Std. } \\
\text { Dev. }\end{array}$ & Mean & $\begin{array}{l}\text { Std. } \\
\text { Dev. }\end{array}$ \\
\hline \multicolumn{5}{|l|}{ Part-Time as percent of Total } \\
\hline FTE & 0.216 & 0.021 & 0.247 & 0.206 \\
\hline percent Employer Contribution & 0.732 & 0.234 & 0.748 & 0.240 \\
\hline Employer Contribution $^{a}$ & 4540.500 & 2758.780 & 4589.313 & 2896.274 \\
\hline percent Unemployment & 4.710 & 1.860 & 4.840 & 1.880 \\
\hline Construction & 0.038 & 0.190 & 0.040 & 0.195 \\
\hline Transportation/Utility & 0.025 & 0.155 & 0.018 & 0.132 \\
\hline Wholesale Trade & 0.055 & 0.228 & 0.056 & 0.231 \\
\hline Retail Trade & 0.207 & 0.405 & 0.263 & 0.440 \\
\hline Professional Services & 0.200 & 0.400 & 0.170 & 0.375 \\
\hline Agriculture & 0.007 & 0.085 & 0.006 & 0.079 \\
\hline Finance, Insurance, Real Est. & 0.072 & 0.259 & 0.084 & 0.278 \\
\hline Other Services & 0.307 & 0.461 & 0.310 & 0.463 \\
\hline Mining/Manufacturing & 0.089 & 0.285 & 0.053 & 0.224 \\
\hline percentFemale >50 (0/1 var) & 0.404 & 0.491 & 0.412 & 0.492 \\
\hline Female Missing & 0.165 & 0.371 & 0.169 & 0.375 \\
\hline percentAge $>50$ & 0.153 & 0.182 & 0.154 & 0.197 \\
\hline Age Missing & 0.194 & 0.396 & 0.199 & 0.399 \\
\hline percentLow Wage > 50 (0/1 var) & 0.183 & 0.386 & 0.188 & 0.391 \\
\hline Low Wage Missing & 0.181 & 0.385 & 0.190 & 0.392 \\
\hline Operating <1 yr & 0.005 & 0.072 & 0.007 & 0.083 \\
\hline Operating 1-2 yrs & 0.025 & 0.155 & 0.033 & 0.178 \\
\hline Operating $3-4$ yrs & 0.038 & 0.190 & 0.041 & 0.198 \\
\hline Operating 5-9 yrs & 0.098 & 0.297 & 0.103 & 0.304 \\
\hline Operating 10-19 yrs & 0.190 & 0.393 & 0.195 & 0.396 \\
\hline Operating $>=20 y r s$ & 0.477 & 0.499 & 0.446 & 0.497 \\
\hline Operating Missing & 0.098 & 0.297 & 0.102 & 0.303 \\
\hline Non Profit & 0.122 & 0.328 & 0.103 & 0.304 \\
\hline Unionized & 0.063 & 0.243 & 0.052 & 0.222 \\
\hline Unionized Missing & 0.058 & 0.233 & 0.066 & 0.249 \\
\hline FTE & 108.490 & 458.670 & 28.418 & 111.640 \\
\hline Corporation & 0.749 & 0.434 & 0.748 & 0.434 \\
\hline MultiUnit Establishment & 0.478 & 0.499 & 0.461 & 0.499 \\
\hline Firm Size: Large & 0.281 & 0.449 & 0.259 & 0.438 \\
\hline Firm Size: Medium & 0.303 & 0.459 & 0.205 & 0.404 \\
\hline Firm Size: Small & 0.415 & 0.493 & 0.527 & 0.499 \\
\hline \multicolumn{5}{|l|}{ Establishment Size } \\
\hline 6-24 employees & 0.348 & 0.476 & 0.487 & 0.500 \\
\hline 25-49 employees & 0.149 & 0.356 & 0.136 & 0.342 \\
\hline 50-249 employees & 0.258 & 0.438 & 0.111 & 0.314 \\
\hline 250-999 employees & 0.087 & 0.282 & 0.012 & 0.109 \\
\hline >=1000 employees & 0.023 & 0.148 & 0.001 & 0.035 \\
\hline
\end{tabular}

Number of observations $=37635$

$\mathrm{a}_{2004 \text { constant dollars }}$ 
Table 2. Effect of Employer Contribution on Demand for Part-Time Workers--IV Results

\begin{tabular}{|c|c|c|c|c|}
\hline Independent Variables & Coef. & Std. Err. & $P>|t|$ & Elasticity \\
\hline HI Employer Contribution & 0.0002 & 0.0001 & 0.00 & 3.6569 \\
\hline $\begin{array}{l}\text { \% Unemployment } \\
\text { Industry }\end{array}$ & -0.0084 & 0.0035 & 0.02 & -0.1635 \\
\hline Construction & 0.0441 & 0.0295 & 0.14 & 0.0071 \\
\hline Transportation/Utility & 0.0861 & 0.0329 & 0.01 & 0.0062 \\
\hline Wholesale Trade & -0.0131 & 0.0288 & 0.65 & -0.0030 \\
\hline Retail Trade & 0.2205 & 0.0329 & 0.00 & 0.2345 \\
\hline Professional Services & 0.1007 & 0.0242 & 0.00 & 0.0692 \\
\hline Agriculture & -0.1523 & 0.1003 & 0.13 & -0.0038 \\
\hline Finance, Insurance, Real Est. & 0.0107 & 0.0240 & 0.66 & 0.0036 \\
\hline Other Services & 0.1638 & 0.0211 & 0.00 & 0.2055 \\
\hline$\%$ Female >50 (0/1) & 0.0902 & 0.0220 & 0.00 & 0.1504 \\
\hline Female Missing & 0.0375 & 0.0266 & 0.16 & 0.0257 \\
\hline$\%$ Age $>50$ & -0.3609 & 0.1182 & 0.00 & -0.2246 \\
\hline Age Missing & -0.0456 & 0.0283 & 0.11 & -0.0367 \\
\hline \%Low Wage > $50(0 / 1)$ & 0.2715 & 0.0310 & 0.00 & 0.2067 \\
\hline Low Wage Missing & 0.0650 & 0.0234 & 0.01 & 0.0500 \\
\hline Operating $<1 \mathrm{yr}$ & -0.0242 & 0.0895 & 0.79 & -0.0007 \\
\hline Operating 1-2 yrs & 0.0400 & 0.0304 & 0.19 & 0.0053 \\
\hline Operating 3-4 yrs & 0.0969 & 0.0335 & 0.00 & 0.0160 \\
\hline Operating 5-9 yrs & 0.0467 & 0.0170 & 0.01 & 0.0194 \\
\hline Operating $10-19$ yrs & 0.0313 & 0.0129 & 0.02 & 0.0247 \\
\hline Operating Missing & 0.0389 & 0.0187 & 0.04 & 0.0161 \\
\hline Non Profit & -0.1662 & 0.0647 & 0.01 & -0.0691 \\
\hline Unionized & -0.1579 & 0.0426 & 0.00 & -0.0332 \\
\hline Unionized Missing & -0.0645 & 0.0273 & 0.02 & -0.0173 \\
\hline FTE Employees & -0.0001 & 0.0000 & 0.00 & -0.0157 \\
\hline FTE Employees Squared & 0.0000 & 0.0000 & 0.01 & 0.0005 \\
\hline 1996 & 0.0560 & 0.0260 & 0.03 & 0.0211 \\
\hline 1997 & 0.0790 & 0.0262 & 0.00 & 0.0364 \\
\hline 1998 & 0.0636 & 0.0230 & 0.01 & 0.0338 \\
\hline 1999 & 0.0173 & 0.0186 & 0.35 & 0.0106 \\
\hline 2000 & -0.0635 & 0.0331 & 0.06 & -0.0154 \\
\hline 2001 & -0.0986 & 0.0373 & 0.01 & -0.0443 \\
\hline 2002 & -0.0633 & 0.0299 & 0.03 & -0.0276 \\
\hline 2003 & -0.0105 & 0.0208 & 0.61 & -0.0049 \\
\hline Constant & -0.8526 & 0.2950 & 0.00 & \\
\hline $\mathrm{N}$ & \multicolumn{2}{|c|}{37635} & & \\
\hline Chi Square & \multicolumn{2}{|c|}{0.0000} & & \\
\hline
\end{tabular}

Notes: Unreported covariates include state dummy variables. Omitted variables: industry group-mining/manufacturing, operating $>=20 y r s, 2004$. 
Table 3. Effect of Employer Contribution on Demand for Part-Time Workers--OLS Results

\begin{tabular}{|c|c|c|c|c|}
\hline Independent Variables & Coef. & Std. Err. & $P>|t|$ & Elasticity \\
\hline HI Employer Contribution & 0.00000322 & 0.0000 & 0.00 & 0.0598 \\
\hline$\%$ Unemployment & -0.0012 & 0.0008 & 0.15 & -0.0240 \\
\hline Construction & 0.0399 & 00057 & مOחת & 0.0064 \\
\hline Transportation/Utility & 0.0519 & 0.0076 & 0.00 & 0.0037 \\
\hline Wholesale Trade & 0.0216 & 0.0053 & 0.00 & 0.0049 \\
\hline Retail Trade & 0.1342 & 0.0048 & 0.00 & 0.1427 \\
\hline Professional Services & 0.0608 & 0.0050 & 0.00 & 0.0417 \\
\hline Agriculture & 0.0956 & 0.0172 & 0.00 & 0.0024 \\
\hline Finance, Insurance, Real Est. & 0.0318 & 0.0055 & 0.00 & 0.0109 \\
\hline Other Services & 0.1415 & 0.0047 & 0.00 & 0.1775 \\
\hline$\%$ Female >50 (0/1) & 0.0327 & 0.0032 & 0.00 & 0.0545 \\
\hline Female Missing & 0.0313 & 0.0094 & 0.00 & 0.0214 \\
\hline$\%$ Age $>50$ & -0.0047 & 0.0077 & 0.54 & -0.0029 \\
\hline Age Missing & 0.0096 & 0.0072 & 0.19 & 0.0077 \\
\hline$\%$ Low Wage > $50(0 / 1)$ & 0.1822 & 0.0042 & 0.00 & 0.1387 \\
\hline Low Wage Missing & 0.0335 & 0.0077 & 0.00 & 0.0257 \\
\hline Operating $<1 \mathrm{yr}$ & 0.0200 & 0.0178 & 0.26 & 0.0006 \\
\hline Operating 1-2 yrs & 0.0270 & 0.0083 & 0.00 & 0.0036 \\
\hline Operating 3-4 yrs & 0.0269 & 0.0068 & 0.00 & 0.0044 \\
\hline Operating 5-9 yrs & 0.0271 & 0.0045 & 0.00 & 0.0113 \\
\hline Operating $10-19$ yrs & 0.0149 & 0.0035 & 0.00 & 0.0117 \\
\hline Operating Missing & 0.0082 & 0.0061 & 0.18 & 0.0034 \\
\hline Non Profit & 0.0343 & 0.0049 & 0.00 & 0.0143 \\
\hline Unionized & -0.0383 & 0.0056 & 0.00 & -0.0081 \\
\hline Unionized Missing & -0.0039 & 0.0077 & 0.61 & -0.0011 \\
\hline FTE Employees & -0.0003 & 0.0000 & 0.00 & -0.0298 \\
\hline FTE Employees Squared & 0.0000 & 0.0000 & 0.00 & 0.0010 \\
\hline 1996 & 0.0004 & 0.0063 & 0.95 & 0.0002 \\
\hline 1997 & 0.0161 & 0.0059 & 0.01 & 0.0074 \\
\hline 1998 & 0.0200 & 0.0055 & 0.00 & 0.0106 \\
\hline 1999 & 0.0317 & 0.0054 & 0.00 & 0.0195 \\
\hline 2000 & 0.0106 & 0.0071 & 0.14 & 0.0026 \\
\hline 2001 & 0.0007 & 0.0057 & 0.90 & 0.0003 \\
\hline 2002 & 0.0087 & 0.0059 & 0.14 & 0.0038 \\
\hline 2003 & 0.0132 & 0.0059 & 0.03 & 0.0061 \\
\hline Constant & 0.0711 & 0.0105 & 0.00 & \\
\hline $\mathrm{N}$ & \multicolumn{2}{|l|}{37635} & & \\
\hline R-squared & \multicolumn{2}{|l|}{0.2550} & & \\
\hline
\end{tabular}

Notes: Unreported covariates include state dummy variables. Omitted variables: industry group-mining/manufacturing,

operating >=20yrs, 2004. 
Table 4. Determinants of Employer Contribution

\begin{tabular}{|c|c|c|c|}
\hline Independent Variables & Coef. & Std. Err. & $P>|t|$ \\
\hline \% Unemployment & 36.78 & 12.73 & 0.00 \\
\hline \multicolumn{4}{|l|}{ Industry } \\
\hline Construction & -20.42 & 150.99 & 0.89 \\
\hline Transportation/Utility & -179.00 & 152.17 & 0.24 \\
\hline Wholesale Trade & 184.75 & 131.76 & 0.16 \\
\hline Retail Trade & -446.01 & 99.17 & 0.00 \\
\hline Professional Services & -212.70 & 107.71 & 0.05 \\
\hline Agriculture & 1230.22 & 305.62 & 0.00 \\
\hline Finance, Insurance, Real Est. & 92.09 & 112.81 & 0.41 \\
\hline Other Services & -145.70 & 101.16 & 0.15 \\
\hline$\%$ Female > $50(0 / 1)$ & -300.78 & 53.80 & 0.00 \\
\hline Female Missing & -23.48 & 124.99 & 0.85 \\
\hline$\%$ Age $>50$ & 1824.11 & 148.87 & 0.00 \\
\hline Age Missing & 279.90 & 105.23 & 0.01 \\
\hline \%Low Wage > $50(0 / 1)$ & -463.38 & 60.27 & 0.00 \\
\hline Low Wage Missing & -168.80 & 101.31 & 0.10 \\
\hline Operating $<1 \mathrm{yr}$ & 172.17 & 437.62 & 0.69 \\
\hline Operating 1-2 yrs & -88.90 & 156.64 & 0.57 \\
\hline Operating 3-4 yrs & -378.37 & 118.69 & 0.00 \\
\hline Operating 5-9 yrs & -111.02 & 80.29 & 0.17 \\
\hline Operating 10-19 yrs & -91.94 & 59.08 & 0.12 \\
\hline Operating Missing & -163.70 & 78.46 & 0.04 \\
\hline Non Profit & 969.96 & 79.31 & 0.00 \\
\hline Unionized & 622.48 & 90.49 & 0.00 \\
\hline Unionized Missing & 316.34 & 95.69 & 0.00 \\
\hline FTE Employees & -0.62 & 0.11 & 0.00 \\
\hline FTE Employees Squared & 0.00 & 0.00 & 0.00 \\
\hline 1996 & -295.19 & 93.24 & 0.00 \\
\hline 1997 & -331.88 & 85.71 & 0.00 \\
\hline 1998 & -241.66 & 89.04 & 0.01 \\
\hline 1999 & 61.52 & 87.41 & 0.48 \\
\hline 2000 & 365.27 & 117.99 & 0.00 \\
\hline 2001 & 494.13 & 92.86 & 0.00 \\
\hline 2002 & 350.02 & 92.09 & 0.00 \\
\hline 2003 & 121.92 & 93.65 & 0.19 \\
\hline Corporate Status & -176.34 & 53.65 & 0.00 \\
\hline Constant & 4932.79 & 182.09 & 0.00 \\
\hline $\mathrm{N}$ & 37635 & & \\
\hline R-squared & 0.083 & & \\
\hline
\end{tabular}

Notes: Unreported covariates include state dummy variables. Omitted variables: industry group-mining/manufacturing,

operating $>=20 y r s, 2004$. 